\title{
A Comment on Chinese Policies to Avoid Negative Impacts on River Ecosystems by Hydropower Projects
}

\author{
Miao Wu ${ }^{1}$, Ang Chen ${ }^{2}$ (D), Xingnan Zhang 1,3,4,*(D) and Michael E. McClain 5,6 \\ 1 College of Hydrology and Water Resources, Hohai University, Nanjing 210098, China; 3water@hhu.edu.cn \\ 2 Yangtze Ecology and Environment Co., Ltd., Wuhan 430062, China; angteenchen@gmail.com \\ 3 National Cooperative Innovation Center for Water Safety \& Hydro-Science, Hohai University, \\ Nanjing 210098, China \\ 4 National Engineering Research Center of Water Resources Efficient Utilization and Engineering Safety, \\ Hohai University, Nanjing 210098, China \\ 5 Department of Water Resources and Ecosystems, IHE Delft Institute for Water Education, 2611AX Delft, \\ The Netherlands; m.mcclain@un-ihe.org \\ 6 Faculty of Civil Engineering and Geosciences, Delft University of Technology, 2628CN Delft, \\ The Netherlands \\ * Correspondence: xingnan.zhang@outlook.com or zxn@hhu.edu.cn
}

Received: 24 February 2020; Accepted: 18 March 2020; Published: 20 March 2020

check for updates

\begin{abstract}
The rapid economic development of river basins depends on the excessive use of water resources. China experienced a rapid development of hydropower projects in the last two decades and thus faces many ecological and environmental issues, especially in ecologically sensitive areas. Environmental flow is an important management tool that requires attention in the environmental impact assessment of hydropower projects. Environmental flows are of great significance for maintaining river structures and protecting the health of both aquatic ecosystems and human sustainable livelihoods. Although the government authorities have done much work in this area and attempted to consider technical requirements to address the negative externalities of hydropower projects, there are still defects in the basic procedures, calculation methods, and ultimately implementation process from policy to operationalization in terms of environmental flows. The official standards for environmental flows assessment mainly appear in two documents: 1 . specification for calculation of environmental flow in rivers and lakes; and 2. code for calculation ecological flow of hydropower projects. This paper reviewed the overarching framework of the two documents and then summarized their fitness in terms of environmental flows implementation in hydropower projects. The research status of environmental flows and future directions for China were also proposed in this paper.
\end{abstract}

Keywords: environmental flows; ecological flow; China; hydropower; river ecosystem

\section{Introduction}

Hydropower in China has been developing rapidly for the past 20 years and the government encourages the development and utilization of renewable energy. Nearly one hundred thousand of multi-objective dams have been constructed, hydropower stations account for a half [1,2]. Hydropower stations are supposed to protect the ecosystems by clean electricity production and take into account the requirements of flood control, water supply, irrigation, shipping and fisheries [3]. The unguaranteed inflow is the direct cause of the insufficient ecological flow of some rivers and lakes [4]. Over-exploitation of water resources has brought serious threats to the ecosystem, such as the hydropower project has greatly changed river flow regimes [5-7]. To prevent more human disturbance from harming the ecosystem, the government of China (GoC) has made great efforts to promote ecological sustainability [8]. 
Unnatural flow alternations negatively influence ecosystems [9-11]. Since 2006, GoC has issued many relevant guidelines or standards to promote the sustainable development of water resources (Table 1). In these guidelines, the purpose of river environmental base flow is to prevent the river flow from being cut off and to avoid minimum flows that might cause irreversible damage of river aquatic communities. Water conservancy projects and hydropower projects are required to take measures to protect the environmental base flow both in the construction and operation period [12,13]. It is clear that most of the key disturbances in the flow state come from in-stream water works, which are designed to store water during the rainy season and transfer it downstream as needed. Maintaining the environmental flows as designed is an effective way to protect river ecosystems [14]. The environmental flows management of dammed rivers in China can be implemented in accordance with relevant official guidelines to ensure the health of the ecosystem.

Table 1. Typical guidelines for environmental flows issued by Chinese authorities.

\begin{tabular}{|c|c|c|}
\hline Issuing Authority & Guideline & Related Content \\
\hline $\begin{array}{l}\text { State Environmental } \\
\text { Protection } \\
\text { Administration }\end{array}$ & $\begin{array}{l}\text { Technical guide for environmental impact } \\
\text { assessment of river ecological flow, cold } \\
\text { water, and fish passage facilities for water } \\
\text { conservation construction projects (trial) } \\
\text { EIA Letter (2006) No.4 }\end{array}$ & $\begin{array}{c}\text { The lower limit of the ecological base flow } \\
\text { should not be less than } 10 \% \text { of the average } \\
\text { annual natural runoff. }\end{array}$ \\
\hline $\begin{array}{c}\text { Ministry of Water } \\
\text { Resources }\end{array}$ & $\begin{array}{c}\text { Technical specification for the analysis of } \\
\text { supply and demand balance of water } \\
\text { resources (SL 429-2008) }\end{array}$ & $\begin{array}{l}\text { Ecological base flow generally takes the } \\
\text { minimum monthly average flow of } 90 \% \text { of the } \\
\text { control nodes; the minimum ecosystems } \\
\text { water demand in the river, and the average } \\
\text { annual runoff of the control nodes in the north } \\
\text { is generally } 10-20 \%, 20-30 \% \text { in the south. } \\
\text { The eco-hydrological elements of water } \\
\text { project planning and design should consider } \\
\text { the ecological base flow and sensitive } \\
\text { ecological water demand at the river basin } \\
\text { scale, river corridor scale and river scale, and } \\
\text { further standardize. }\end{array}$ \\
\hline
\end{tabular}

Due to the significant regional differences in climate and geography in China, how to determine the environmental flows in a logical process is challenging for water managers. It is imperative that environmental flows be quantified and implemented. Considerable research has been done on the definition of environmental flows in China, the development of calculation methods, and implementation of environmental flows, including the selection of indicators for monitoring [15-18]. Given this level of research, no specific provisions on environmental flows have been formulated [3]. Where they do appear, environmental flows are grouped with other demands and given unclear priority. For example, the new "Water Law of the People's Republic of China" promulgated in 2016 states that "the development and utilization of water resources should first meet the requirements of urban and rural residents, and take into account the needs of agriculture, industry, ecosystems and shipping". In the development and utilization of water resources in semi-arid areas, the ecosystems needs be fully considered [6]. In the related norms, there are some recommend methods to calculate environmental flows. Previous studies $[19,20]$ have conducted research into the advantages and disadvantages of environmental flows calculation methods and applicable conditions for a specific area or region. In order to maximize the use of environmental flows calculation specifications, it is time to comprehensively sort out GoC's calculation of environmental flows, analyzing the relevant normative standards, the environmental flows calculation principles and recommended methods proposed in the different normative guidelines. In the rest of this comment, we review the related policies on environmental flows release from hydropower projects in China and summarize the defects in the current policy. This provides not only effective suggestions for environmental flows research, but also some empirical reference for environmental flows practices. 


\section{Description of the Two Standards for Development of Water Use Projects}

There are two main standards for development of water use projects for the environmental flows, the 2015 "Specification for calculation of environmental flow in rivers and lakes" (SERL) [21] which applies in all water conservancy projects and the 2017 "Code for calculation of ecological flow of hydropower projects" (CEHP) [22] which applies specifically to hydropower projects. They are the two latest and important specifications of $\mathrm{GoC}$ on the principles and calculation methods of environmental flows. The standards are state-of-the art in requiring that flows be set to protect a broad range of ecological processes, including migrations, spawning, and other habitat requirements. In general, SERL is the reference basis for CEHP, and CEHP is a sector-specific (hydropower) analysis of environmental flow calculations for rivers. Therefore, in the actual operation process, the manager must make the discharge flow meet the requirements of SERL, and also meet the specific regulations in CEHP.

About the compilation process of preparing the standards, on the basis of in-depth research, the compiler summarized the practical experience of relevant environmental flows calculations, incorporated the scientific and technological achievements of relevant research, and solicited opinions from relevant design units and scientific research experts. Although they are both standards for development of water use projects of the People's Republic of China for the calculation of environmental flows, they also have many differences (Table 2). The two standards come from different government authorities and the objects are different. Additionally, there are differences in the objectives and purposes of their implementation, but they do not exist independently. From the point of view of the title, SERL covers a wider range and content than CEHP.

Table 2. Comparison of the two standards for development of water use projects for calculating environmental flows in China.

\begin{tabular}{|c|c|c|}
\hline Guideline & SERL & CEHP \\
\hline Issued authority & $\begin{array}{c}\text { Ministry of Water Resources of the People's } \\
\text { Republic of China }\end{array}$ & National Energy Administration of China \\
\hline Purpose & $\begin{array}{l}\text { Technical requirements, basic procedures and } \\
\text { calculation methods for regulating the } \\
\text { ecosystems of rivers and lakes in order to protect } \\
\text { and restore the ecosystems of rivers and lakes }\end{array}$ & $\begin{array}{l}\text { In order to standardize the conditions, } \\
\text { contents and methods for calculating the } \\
\text { ecological flow of hydropower projects }{ }^{1} \text {, } \\
\text { and to unify the technical requirements, } \\
\text { this specification is formulated. }\end{array}$ \\
\hline Object & $\begin{array}{l}\text { It is applicable to the ecosystems water demand } \\
\text { calculation and water project }{ }^{2} \text { planning, design } \\
\text { and management of water environment } \\
\text { integration and professional planning for } \\
\text { watershed and regional ecosystems water } \\
\text { demand calculation }\end{array}$ & $\begin{array}{l}\text { It is suitable for the analysis and } \\
\text { calculation of ecological flow of } \\
\text { hydropower projects }{ }^{1} \text {. }\end{array}$ \\
\hline
\end{tabular}

\footnotetext{
${ }^{1}$ Hydropower projects: the first main use is hydropower generation. ${ }^{2}$ Water conservancy projects: the first main use is not hydropower generation.
}

\section{Comparison Analysis of the Two Standards for Development of Water Use Projects}

\subsection{Basic Principles}

The SERL stipulates that environmental flows should be considered at a river basin scale and not only for individual river reaches. On the basis of water resources development, environmental protection and social and economic development, the environmental flows can be determined scientifically and reasonably [23-25]. The environmental flow method selected by the manager depends on the ecological conditions and data availability in the downstream, such as the rare species, spawning area, wetland or historic landscape existed in the downstream. These requirements also apply to CEHP. It is worth noting that CEHP emphasizes the consideration of river fish resources, water quality deterioration, saltwater intrusion, algal blooms and other ecological and environmental issues, but also needs to consider the downstream of hydropower projects construction and operation. Eco-environmental problems are also to be considered, such as changes in hydrological conditions 
in the river section, insufficient water supply to connected wetlands, and weakened aquatic habitats. From the basic principle, the two standards are similar, but the impact of the operation of water development projects is emphasized in CEHP.

\subsection{Components and Definition of Terms}

Environmental flows in rivers and lakes, in-stream environmental flow, off-stream environmental flow, in-stream fundamental environmental flow, in-stream targeted environmental flow are defined in the SERL. In CEHP, ecological flow, aquatic ecological flow needs, aquatic ecological base flow, riparian wetland flow needs, environment flow needs, scenery flow needs, estuary ecological flow needs and in-stream groundwater recharge needs are defined (Table 3). In terms of components, the names of the definitions are inconsistent (Table 4), but the purpose is to protect the river ecosystem in a healthy condition. Additionally, in order to facilitate management, both guidelines divide the environmental flows into two parts, which are basic (fundamental/base) flow and target flow. Considering the scope of application, the environmental flows are divided into two categories that are in-stream environmental flows and off-stream environmental flows. Through the analysis of the definitions of each term in the two standards for development of water use projects, we refer to the subject discussed in this paper as environmental flows that is the in-stream environmental flows impacted by the hydropower projects.

Table 3. The comparison of application of the two standards for development of water use projects.

\begin{tabular}{ccc}
\hline Category & SERL & CEHP \\
\hline In-stream environmental flow & River, Lake, Swamp & $\begin{array}{c}\text { River, Riparian wetland, Scenery, } \\
\text { Estuary, In-stream groundwater, }\end{array}$ \\
& $\begin{array}{c}\text { Urban green space } \\
\text { Urban sanitation } \\
\text { Off-stream environmental flow }\end{array}$ & Ecological grassland \\
& Rivers, lakes and marshes \\
& replenish water & \\
\hline
\end{tabular}

Table 4. Comparison of key terms definitions of the two standards for development of water use projects.

\begin{tabular}{|c|c|c|}
\hline Guideline & Main Terms & Definition \\
\hline \multirow{3}{*}{ SERL } & In-stream environmental flow & $\begin{array}{l}\text { In order to maintain the ecological and environmental } \\
\text { protection goals of rivers, lakes and marshes. }\end{array}$ \\
\hline & $\begin{array}{l}\text { In-stream fundamental } \\
\text { environmental flow }\end{array}$ & The minimum amount of water in the river. \\
\hline & $\begin{array}{l}\text { In-stream targeted } \\
\text { environmental flow }\end{array}$ & $\begin{array}{l}\text { The amount of water retained in the river to maintain the } \\
\text { ecological and environmental functions. }\end{array}$ \\
\hline \multirow{4}{*}{ CEHP } & Off-stream environmental flow & $\begin{array}{c}\text { Artificial water supply in order to achieve certain } \\
\text { ecological goals. }\end{array}$ \\
\hline & Ecological flow & $\begin{array}{l}\text { In order to ensure the flow for ecosystem in the } \\
\text { downstream reach of hydropower project. }\end{array}$ \\
\hline & Aquatic ecological flow needs & $\begin{array}{c}\text { Suitable flow to guarantee the basic stability of the aquatic } \\
\text { ecosystem in the downstream sections of hydropower } \\
\text { projects. }\end{array}$ \\
\hline & Aquatic ecological base flow & $\begin{array}{l}\text { Minimum flow to guarantee the basic quality of aquatic } \\
\text { habitat in the downstream sections of hydropower projects. }\end{array}$ \\
\hline
\end{tabular}

\subsection{Analysis of the Calculation Process}

The two documents both summarize the assessment of environmental flows into several similar and effective steps. The first step is to collect the basic data of the river. The second step is to determine the ecological objectives (sensitive ecosystems protection objectives: nature reserves, important wetlands, natural forests, rare and endangered wildlife nature reserves, natural spawning grounds, 
etc.). The third step is to analyze and calculate the environmental flows by different methods. The fourth step is the comprehensive analysis of environmental flows in the specific river.

In the $\mathrm{CEHP}$, there is a clear formulation to calculate the environmental flows, as follows:

$$
Q_{\text {st }}(t)=\operatorname{Max}\left(Q_{s s}(t), Q_{s h}(t), Q_{j g}(t), Q_{h k}(t)\right)+Q_{h l}(t)+Q_{d x}(t)
$$

where

$Q_{s t}(t)$ is the environmental flows $\left(\mathrm{m}^{3} / \mathrm{s}\right)$;

$Q_{s s}(t)$ is the aquatic ecological flow needs $\left(\mathrm{m}^{3} / \mathrm{s}\right)$;

$Q_{s h}(t)$ is the environmental flow $\left(\mathrm{m}^{3} / \mathrm{s}\right)$ which is considered by the water quality and water environmental functions (shipping);

$Q_{j g}(t)$ is the water required for landscape and ecology $\left(\mathrm{m}^{3} / \mathrm{s}\right)$;

$Q_{h k}(t)$ is the estuary environmental flow needs $\left(\mathrm{m}^{3} / \mathrm{s}\right) ; d x$

$Q_{h l}(t)$ is the river riparian wetland flow needs $\left(\mathrm{m}^{3} / \mathrm{s}\right)$;

$Q_{d x}(t)$ is the in-stream groundwater recharge needs $\left(\mathrm{m}^{3} / \mathrm{s}\right)$.

In the SERL, there is no deterministic equation to calculate the environmental flows. A framework is explicitly presented to guide managers on how to determine the environmental flows (Figure 1). Because the calculation of environmental flows is a complicated process, various factors need be considered at the same time. Thus, this frame diagram has a certain reference, but its operability is not strong.

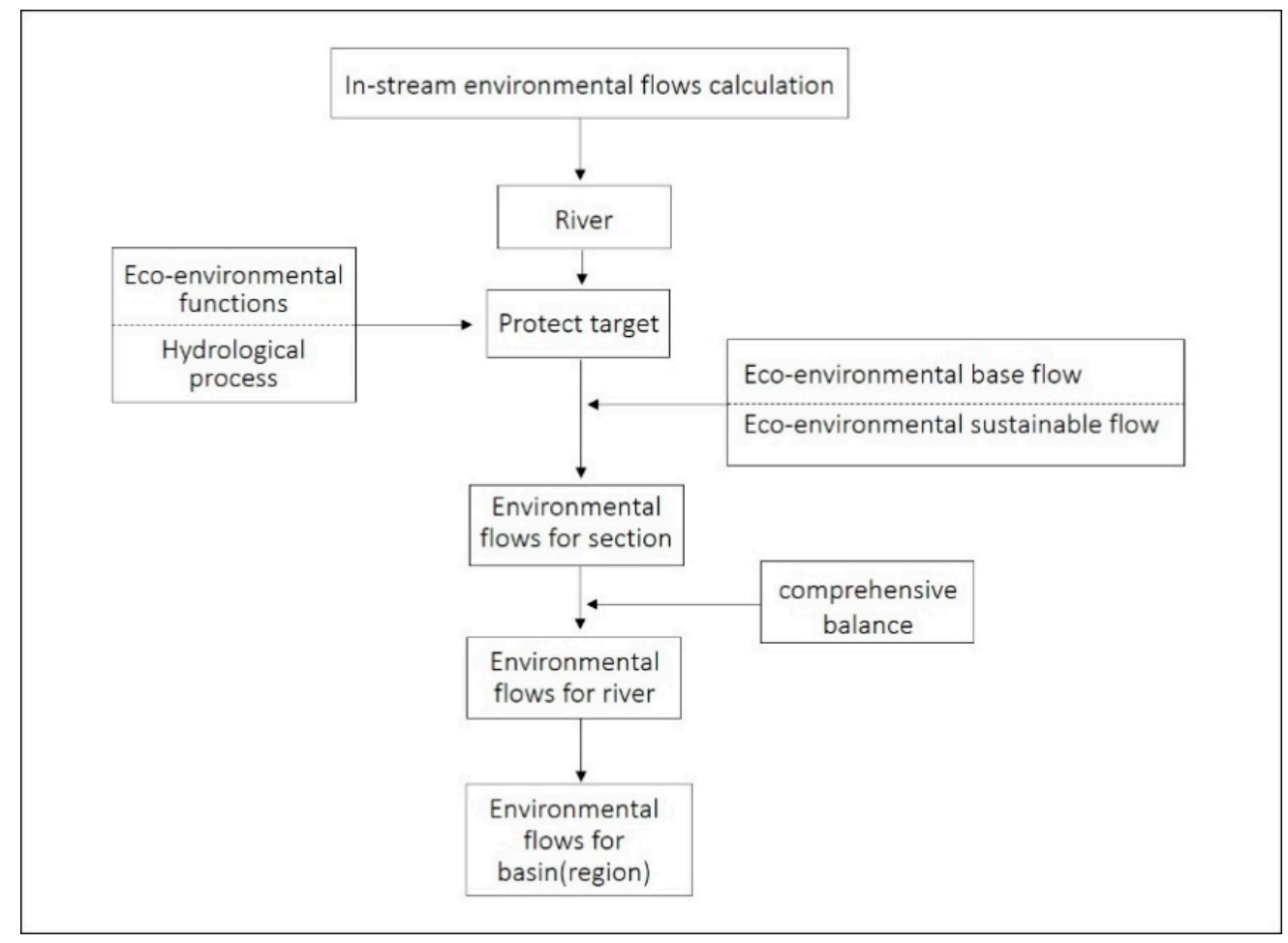

Figure 1. Framework for determining the in-stream environmental flows in SERL.

\subsection{Recommended Methods}

The environmental flows calculations we discuss here, according to the analysis, correspond to the in-stream environmental flows and aquatic ecological flow needs in the two standards (may vary due to different definitions of terms). Both standards mention that in the stage of method selection, it is necessary to choose the appropriate method according to different objects. Although many 
types of methods are recommended in the standards, there is no specific explanation on the methods selection principle (Table 5). In the process of how to determine the eco-environmental protection objectives, SERL mentions that the protection objectives should be reasonably determined according to the development and utilization of water resources in the basin. In CEHP, it is mentioned that the eco-environmental protection objectives should be reasonably determined by the downstream hydrological conditions and the aquatic ecology. Obviously, there are significant differences between the two standards in determining the protection objectives. CEHP is more specific on hydropower protection objectives and the SERL is broader to cover all rivers and lakes.

Table 5. Recommended methods of the two standards for development of water use projects.

\begin{tabular}{lcr}
\hline Guideline & \multicolumn{1}{c}{ Objects } & \multicolumn{1}{c}{ Methods } \\
\hline SERL & $\begin{array}{c}\text { In-stream fundamental } \\
\text { environmental flow } \\
\text { In-stream targeted } \\
\text { environmental flow }\end{array}$ & $\begin{array}{c}\text { Qp }{ }^{1} \text {,7Q10, The most dry month method (MDM) }{ }^{2} \text {, Flow } \\
\text { duration curve method, Tennant, Frequency curve method, } \\
\text { Wetted perimeter method, Habitat analysis method, River } \\
\text { bed morphology analysis method. }\end{array}$ \\
CEHP & Aquatic ecological flow needs & $\begin{array}{c}\text { Tennant, Frequency curve method, Habitat analysis method. } \\
\text { Wetted perimeter method, R2-CROSS method, Eco-hydraulic } \\
\text { method, Habitat analysis method, Tennant, 7Q10. } \\
\text { Wetted perimeter method, R2-CROSS method, } \\
\text { Eco-hydraulic method, Tennant, 7Q10. }\end{array}$ \\
\hline
\end{tabular}

\footnotetext{
${ }^{1}$ Qp: This method uses different flow percentile (It depends on the water manager) as the result. ${ }^{2}$ MDM: This method uses the driest month flow as the corresponding month result.
}

Additionally, during the calculating process, there are many differences in the two documents. In the SERL, the in-stream environmental flows include the in-stream fundamental environmental flow and the in-stream targeted environmental flow. The in-stream fundamental environmental flow needs to be fully assessed by the minimum value, the values during different time periods of the year and the annual value. Among them, the minimum value and the annual value are calculated by the hydrological methods, and the hydraulic method and the wet perimeter method can be selected under the conditions of sufficient data during different periods of the year. The in-stream targeted environmental flow is to maintain the water demand requirement at the normal level according to the ecosystems function corresponding to the protection target. Then, the in-stream targeted environmental flow will be calculated in different periods and as an annual value. For more accurate and reasonable results, the SERL recommends that managers could use a variety of methods to compare the results and analysis to determine in-stream environmental flow.

It is mentioned in CEHP that the calculation of aquatic ecological flow needs to consider the hydrological characteristics and aquatic ecological protection objectives. This requirement is basically the same as in SERL. It is clearly stated in CEHP that when there is no important fish spawning area in the downstream, the aquatic ecological base flow should be analyzed and calculated. When there are important fish spawning fields, it is necessary to analyze and calculate the hydrological processes required for the aquatic ecological base flow and fish breeding period. The hydraulics, ecological hydraulics, and hydrology methods are recommended for the calculation of aquatic ecological base flow. The aquatic ecological flow needs for the fish breeding period can be calculated by the habitat analysis method. Additionally, the standard requires that at least two methods be used to calculate the aquatic ecological base flow and then based on the experts to choose a better one. During the fish breeding period, the requirements of different fish should be all considered, the specific hydrological process should be calculated separately, and the maximum should be taken as the result. Finally, the water manager should consider the recommended environmental flows threshold (Table 6), according to the size of the river area, the climatic conditions of the geographical location and the current water resources of the river to determine the final environmental flows. 
Table 6. Recommended environmental flows thresholds ${ }^{1}$ for different rivers in China.

\begin{tabular}{|c|c|c|c|c|c|c|c|}
\hline \multirow{2}{*}{\multicolumn{2}{|c|}{ River Type }} & \multicolumn{2}{|c|}{ High } & \multicolumn{2}{|c|}{ Medium } & \multicolumn{2}{|c|}{ Low } \\
\hline & & Base Flow & Suitable Flow & Base Flow & Suitable Flow & Base Flow & Suitable Flow \\
\hline \multirow{2}{*}{$\mathrm{L}^{2}$} & Nor 5 & $10-20$ & $40-50$ & $15-25$ & $45-55$ & $\geq 25$ & $\geq 60$ \\
\hline & Sou 6 & $20-30$ & $65-80$ & $25-35$ & $70-80$ & $\geq 35$ & $\geq 80$ \\
\hline \multirow{2}{*}{$M^{3}$} & Nor 5 & $10-15$ & $40-50$ & $10-25$ & $40-55$ & $\geq 25$ & $\geq 55$ \\
\hline & Sou 6 & $15-30$ & $60-70$ & $20-35$ & $65-75$ & $\geq 35$ & $\geq 75$ \\
\hline \multirow{2}{*}{$S^{4}$} & Nor 5 & 5-10 & $40-45$ & $10-20$ & $40-50$ & $\geq 20$ & $\geq 50$ \\
\hline & Sou 6 & $15-25$ & $50-60$ & $20-30$ & $55-65$ & $\geq 30$ & $\geq 65$ \\
\hline
\end{tabular}

${ }^{1}$ Environmental flow threshold $=$ environmental flows/Surface available water resources $\times 100 \% .{ }^{2} \mathrm{~L}$ means large river (area $\left.>100,000 \mathrm{~km}^{2}\right) .{ }^{3} \mathrm{M}$ means medium river $\left(10,000 \mathrm{~km}^{2}<\right.$ area $\left.<100,000 \mathrm{~km}^{2}\right) .{ }^{4} \mathrm{~S}$ means small river $(3000$ $\mathrm{km}^{2}<$ area $\left.<10,000 \mathrm{~km}^{2}\right) .{ }^{5}$ Nor means northern of China. ${ }^{6}$ Sou means southern of China.

\section{Weaknesses and Recommendations}

Our examination of the two overarching standards governing environmental flows in China included comparisons of term definitions, calculation processes and calculation methods. Our findings of deficiencies in the two standards summarized below and can provide suggestions for water resources managers.

1. Because the standards come from two different authorities, the definition of related terms is not clear. This may lead to misunderstandings during implementation. Water managers may have errors in textual understanding when using the standards. More seriously, due to differences in understanding, there may be increased misunderstandings between stakeholders.

2. In the process of data collection, both standards mention the collection of watershed hydrology, river topography, aquatic ecology, relevant planning and research results. Although the process of evaluating environmental flows in the standards is scientific, it is difficult to evaluate and implement environmental flows according to the requirements of the standards considering the actual situation.

3. Both standards classify environmental flows into base environmental flows (minimum flows) and targeted environmental flows (variable environmental flows). The purpose of this consideration is to rationally use water resources and then create economic value under the premise of protecting ecosystems. How to trade-off the relationship between environment value and the economic value? There is no operational suggestion for water manager.

4. In the specific calculation process, both standards recommend a variety of calculation methods. The standard also clarifies how to choose the method for base environmental flow and targeted environmental flow. However, most of the methods are hydrological methods, and the results of hydrological calculations often lack consideration of ecological processes. Additionally, most of the rivers lack sufficient data, which can impede the implementation of environmental flows.

5. In the ecological process, both standards recommend habitat analysis methods and consider the relationship between hydrological-ecological responses. However, in the actual process, only the large watersheds in China currently have relevant ecological data, which brings difficulties to river managers. In CEHP, it is recommended that water managers consider the hydrological process of different fish breeding seasons. Due to the difficulty of data collection and long cycle monitoring, this is not feasible in practical work.

6. During the process of verifying the rationality of the results, both standards emphasize the need to use multiple methods for calculations and comparison of results to determine a reasonable hydrological process. This is positive but undoubtedly increases the cost of river management.

7. A reasonable range of parameters is given in the two standards, except for habitat analysis methods. Because habitat analysis methods are always based on a rigorous aquatic ecology survey and expert advice, a reasonable range of habitat parameters can be determined. Due to the many remaining problems in the history of watershed management, the habitat analysis method 
is not available in most rivers in China. Moreover, much upfront capital investment is needed which cannot be used in medium or small river.

8. The unknown long-term change of climate and hydrological conditions will bring unpredictable impacts on the ecosystem, such as the invasion of non-native species caused by the change of environmental conditions (rainfall and temperature under changing conditions) that lead to the failure of traditional calculation methods (provided in the two standards) in practical water resources management.

9. Most of the environmental flow calculation methods recommended in the two standards are from foreign countries, and the portability and preconditons for some of them needs further research.

\section{Conclusions}

Hydropower development has brought huge economic benefits, but the complex water resources and intensive human activities have led to serious ecological and environmental problems. [2]. This also urges $\mathrm{GoC}$ to resolve to do some necessary remedial work, such as issuing relevant policies and encouraging relevant research. In China, some rivers have a high degree of development and utilization, and a large amount of economic and social water use. Environmental flows is one of the important management tools to maintain the ecological function of rivers and control the intensity of water resources development [26]. Strengthening the management of river and lake environmental flows is related to the overall situation of water security and realizing China's goal of an ecological civilization. Based on rich experience on environmental flows around the world [27-29], how to minimize the bad influence on the ecosystem becomes more important in the sustainable world. In this study, based on the GoC issued for the environmental flows policy to do a systematic analysis.

The two major standards for development of water use projects (SERL and CEHP) were developed in the context of the national strategy for protecting the ecosystems (ecological civilization) in order to alleviate the pressure of human activities on river ecosystems in China. They all have strict scientific logic and consider all aspects of the factors. However, as the units set up are different administrative authorities, there are certain deviations in the interpretation and implementation of different managers. Our assessment identified defects in the current guidelines and standards. At present, there are no unified provisions on the concept, connotation and evaluation index of environmental flows in the aspects of laws, regulations, policy systems and planning standards. It leads to confusion in the formulation and management of relevant policies and also has a great impact on the public's understanding and implementation of environmental flows. Therefore, unreasonable environmental flow calculations may seriously affect the sustainable development of the ecosystem [30].

Weakness with SERL and CEHP need to be addressed in several ways. Aim at the defects of the basic concepts and recommend calculation methods in standards. First of all, government needs to encourage research institutions to conduct systematic research on the theoretical problems of environmental flows and promote the development of China's environmental flow research technology to the direction of methodology. Let each industry standardize the basic concept of environmental flows. As for the calculation method, the original method introduced from abroad should be changed. Researchers are encouraged to discriminate between methods, assess their applicability and choose the most appropriate method. Most of the previous [31-33] studies have carried out environmental flow calculations for specific projects. How to reduce the uncertainty and improve the rationality and accuracy of the evaluation results is worth further discussion.

The evaluation and implementation of environmental flows is a complex problem that needs to consider not only the rationality of scientific research, but also the feasibility of engineering [9,34]. As it involves economic benefits, it also needs to consider social and economic benefits. In general, the GoC needs to promote the establishment of a complete set of standards for development of water use projects system, unified connotation and understanding. The relevant government authorities need to establish sound policies to ensure the environmental flow of rivers and lakes in accordance with the standards. Promoting the hierarchical management of river and lake environmental flows guarantees 
and clarifies the responsibilities of authorities at all levels for river and lake environmental flow implementation. We should give priority to ensuring the environmental flow of rivers and lakes and strengthen the unified allocation of water resources in river basins. For different rivers, the requirements of environmental flows need to be considered in a targeted way and water resources need to be allocated in a unified way according to local conditions. The research and implementation of environmental flows in rivers and lakes is a complex and comprehensive work involving multiple authorities, fields and links. Processes for stakeholder engagement should be established. The involvement of society at large in decisions on water resources management is an inevitable consequence of social development, and it is important that the general public be encouraged to participate in such decision-making processes. Eco-environmental impact assessments of hydropower projects are significant and should be comprehensive and consider all of the short- and long-term benefits and drawbacks. Therefore, it is urgent to study river environmental flows assessment frameworks and establish a set of general assessment processes in order to achieve differentiated management for different rivers.

Author Contributions: Conceptualization, M.W. and M.E.M.; Funding acquisition, X.Z.; Methodology, M.W.; Resources, A.C.; Supervision, X.Z. and M.E.M.; Writing-original draft, M.W.; Writing-review and editing, M.W., A.C., X.Z. and M.E.M. All authors have read and agreed to the published version of the manuscript.

Funding: This research was funded by the National Key Research and Development Program (Grant No. 2019YFC0409000) approved by the Ministry of Science and Technology of China and National natural science foundation of China (51420105014). The first author was supported by fellowship from the China Scholarship Council for her visit to IHE Delft Institute for Water Education, Delft, The Netherlands.

Conflicts of Interest: The authors declare no conflict of interest.

\section{References}

1. Li, X.; Chen, Z.; Fan, X.; Cheng, Z. Hydropower development situation and prospects in China. Renew. Sustain. Energy Rev. 2018, 82, 232-239. [CrossRef]

2. Xingang, Z.; Lu, L.; Xiaomeng, L.; Jieyu, W.; Pingkuo, L. A critical-analysis on the development of China hydropower. Renew. Energy 2012, 44, 1-6. [CrossRef]

3. Chen, A.; $\mathrm{Wu}, \mathrm{M}$. Managing for Sustainability: The Development of Environmental Flows Implementation in China. Water 2019, 11, 433. [CrossRef]

4. Benjankar, R.; Jorde, K.; Yager, E.M.; Egger, G.; Goodwin, P.; Glenn, N.F. The impact of river modification and dam operation on floodplain vegetation succession trends in the Kootenai River, USA. Ecol. Eng. 2012, 46, 88-97. [CrossRef]

5. Wang, Y.; Zhang, N.; Wang, D.; Wu, J.; Zhang, X. Investigating the impacts of cascade hydropower development on the natural flow regime in the Yangtze River, China. Sci. Total Environ. 2018, 624, 1187-1194. [CrossRef]

6. Chen, A.; Wu, M.; Chen, K.; Sun, Z.Y.; Shen, C.; Wang, P.Y. Main issues in research and practice of environmental protection for water conservancy and hydropower projects in China. Water Sci. Eng. 2016, 9, 312-323. [CrossRef]

7. $\mathrm{Yu}, \mathrm{B}$. The ecological damage compensation for hydropower development based on trade-offs in river ecosystem services. In Proceedings of the IOP Conference Series: Earth and Environmental Science, Ordos, China, 14-16 April 2017; Volume 64, p. 12047.

8. Hansen, M.H.; Li, H.; Svarverud, R. Ecological civilization: Interpreting the Chinese past, projecting the global future. Glob. Environ. Chang. 2018, 53, 195-203. [CrossRef]

9. Bejarano, M.D.; Sordo-Ward, A.; Gabriel-Martin, I.; Garrote, L. Tradeoff between economic and environmental costs and benefits of hydropower production at run-of-river-diversion schemes under different environmental flows scenarios. J. Hydrol. 2019, 572, 790-804. [CrossRef]

10. Tranmer, A.W.; Marti, C.L.; Tonina, D.; Benjankar, R.; Weigel, D.; Vilhena, L.; McGrath, C.; Goodwin, P.; Tiedemann, M.; Mckean, J.; et al. A hierarchical modelling framework for assessing physical and biochemical characteristics of a regulated river. Ecol. Model. 2018, 368, 78-93. [CrossRef] 
11. Zhang, Y.; Arthington, A.H.; Bunn, S.E.; Mackay, S.; Xia, J.; Kennard, M. Classification of Flow regimes for environmental flow assessment in regulated rivers: The huai river basin, china. River Res. Appl. 2012, 28, 989-1005. [CrossRef]

12. Popa, F.; Dumitran, G.E.; Vuta, L.I.; Tica, E.I.; Popa, B.; Neagoe, A. Impact of the ecological flow of some small hydropower plants on their energy production in Romania. J. Phys. Conf. Ser. 2020, 1426, 12043. [CrossRef]

13. Lu, S.; Dai, W.; Tang, Y.; Guo, M. A review of the impact of hydropower reservoirs on global climate change. Sci. Total Environ. 2020, 711, 134996. [CrossRef] [PubMed]

14. Webb, J.A.; Watts, R.J.; Allan, C.; Conallin, J.C. Adaptive Management of Environmental Flows. Environ. Manag. 2018, 61, 339-346. [CrossRef] [PubMed]

15. Ban, X.; Diplas, P.; Shih, W.; Pan, B.; Xiao, F.; Yun, D. Impact of Three Gorges Dam operation on the spawning success of four major Chinese carps. Ecol. Eng. 2019, 127, 268-275. [CrossRef]

16. Xue, J.; Gui, D.; Zhao, Y.; Lei, J.; Zeng, F.; Feng, X.; Mao, D.; Shareef, M. A decision-making framework to model environmental flow requirements in oasis areas using Bayesian networks. J. Hydrol. 2016, 540, 1209-1222. [CrossRef]

17. Baoligao, B.; Xu, F.; Chen, X.; Wang, X.; Chen, W. Acute impacts of reservoir flushing on fishes in the Yellow River. J. Hydro-Environ. Res. 2016, 13, 26-35. [CrossRef]

18. Yan, Y.; Yang, Z.; Liu, Q.; Sun, T. Assessing effects of dam operation on flow regimes in the lower Yellow River. Procedia Environ. Sci. 2010, 2, 507-516. [CrossRef]

19. Tan, G.; Yi, R.; Chang, J.; Shu, C.; Yin, Z.; Han, S.; Feng, Z.; Lyu, Y. A new method for calculating ecological flow: Distribution flow method. AIP Adv. 2018, 8, 45118. [CrossRef]

20. Kumar, A.U. Assessment of environmental flows using hydrological methods for Krishna River, India. Adv. Environ. Res. 2018, 7, 161-175.

21. China MOWR. Specification for Calculation of Environmental Flow in Rivers and Lakes; China MOWR: Beijing, China, 2015.

22. China NEA. Code for Calculation of Ecological Flow of Hydropower Projects; China NEA: Beijing, China, 2016.

23. Zhang, W.; Peng, H.; Jia, Y.; Ni, G.; Yang, Z.; Zeng, Q. Investigating the Simultaneous Ecological Operation of Dam Gates to Meet the Water Flow Requirements of Fish Spawning Migration. Pol. J. Environ. Stud. 2019, 28, 1967-1980. [CrossRef]

24. Li, W.; Chen, Q.; Cai, D.; Li, R. Determination of an appropriate ecological hydrograph for a rare fish species using an improved fish habitat suitability model introducing landscape ecology index. Ecol. Model. 2015, 311, 31-38. [CrossRef]

25. Yi, Y.; Tang, C.; Yang, Z.; Chen, X. Influence of Manwan Reservoir on fish habitat in the middle reach of the Lancang River. Ecol. Eng. 2014, 69, 106-117. [CrossRef]

26. Arthington, A.H.; Bunn, S.E.; Poff, N.L.; Naiman, R.J. The challenge of providing environmental flow rules to sustain river ecosystems. Ecol. Appl. 2006, 16, 1311-1318. [CrossRef]

27. Acreman, M.C.; Ferguson, A.J.D. Environmental flows and the European Water Framework Directive. Freshwater Biol. 2010, 55, 32-48. [CrossRef]

28. Hecht, J.S.; Lacombe, G.; Arias, M.E.; Dang, T.D.; Piman, T. Hydropower dams of the Mekong River basin: A review of their hydrological impacts. J. Hydrol. 2019, 568, 285-300. [CrossRef]

29. Yi, Y.; Cheng, X.; Yang, Z.; Wieprecht, S.; Zhang, S.; Wu, Y. Evaluating the ecological influence of hydraulic projects: A review of aquatic habitat suitability models. Renew. Sustain. Energy Rev. 2017, 68, 748-762. [CrossRef]

30. Pang, A.; Li, C.; Sun, T.; Yang, W.; Yang, Z. Trade-Off Analysis to Determine Environmental Flows in a Highly Regulated Watershed. Sci. Rep. 2018, 8, 1-11. [CrossRef] [PubMed]

31. Książek, L.; Woś, A.; Florek, J.; Wyrębek, M.; Młyński, D.; Wałega, A. Combined use of the hydraulic and hydrological methods to calculate the environmental flow: Wisloka river, Poland: Case study. Environ. Monit. Assess. 2019, 191, 254. [CrossRef] [PubMed]

32. Beaussier, T.; Caurla, S.; Bellon-Maurel, V.; Loiseau, E. Coupling economic models and environmental assessment methods to support regional policies: A critical review. J. Clean. Prod. 2019, 216, 408-421. [CrossRef] 
33. Kuriqi, A.; Pinheiro, A.N.; Sordo-Ward, A.; Garrote, L. Influence of hydrologically based environmental flow methods on flow alteration and energy production in a run-of-river hydropower plant. J. Clean. Prod. 2019, 232, 1028-1042. [CrossRef]

34. Kuriqi, A.; Pinheiro, A.N.; Sordo-Ward, A.; Garrote, L. Flow regime aspects in determining environmental flows and maximising energy production at run-of-river hydropower plants. Appl. Energy 2019, 256, 113980. [CrossRef]

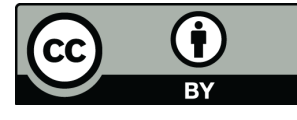

(C) 2020 by the authors. Licensee MDPI, Basel, Switzerland. This article is an open access article distributed under the terms and conditions of the Creative Commons Attribution (CC BY) license (http://creativecommons.org/licenses/by/4.0/). 